\title{
Hubungan Jawa-Bali Abad X-XI
}

\section{Gusti Ayu Surasmi}

Keywords: monarch, inscriptions, archaeology, Old Java, Old Bali

\section{How to Cite:}

Surasmi, I. G. A. Hubungan Jawa-Bali Abad X-XI. Berkala Arkeologi, 14(2), 119_ 122. https://doi.org/10.30883/jba.v14i2.710

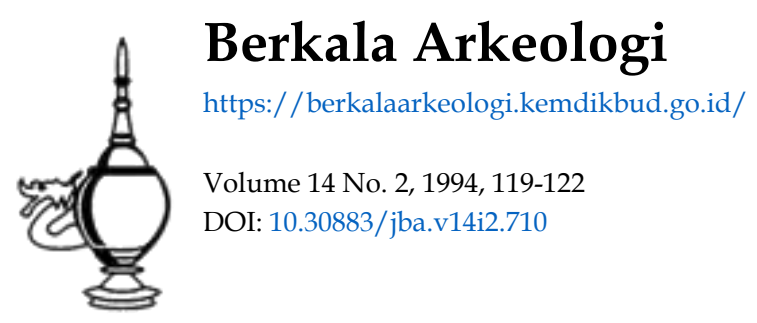

\section{c) (i) (2) (2)}

This work is licensed under a Creative Commons Attribution-NonCommercial-ShareAlike 4.0 International License. 


\title{
HUBUNGAN JAWA - BALI ABAD X - XI
}

\author{
I Gusti Ayu Surasmi \\ (Jurusan Arkeologi FS - UNUD)
}

\section{Pendahuluan}

Indonesıa terdıri darı banyak pulau, namun telah berhasil menunjukkan kebesarannya dalam satu kesatuan sebagai satu negara yang besar. Rasa persatuan dan kesatuan merupakan hal yang sangat penting dalam mewujudkan lestarinya negara kesatuan Indonesia dan hendaknya secara terus menerus dipupuk untuk bisa tetap kuat sebagai dasar mempersatukan seluruh rakyat Indonesıa. Berbicara masalah jiwa persatuan dan kesatuan bangsa indonesia yang tetap ada pada setiap dada bangsa Indonesia tentunya tidak terlepas dari benih-benih awal yang memang telah ada dari masa lampaunya. Rasa persatuan dan kesatuan itu terwujud melalui proses panjang

Sejarah telah membuktikan rakyat Jawa Tengah abad $\mid X-X$ berhasil membangun candicandi yang indah dan megah seperti Borobudur, Prambanan. Sewu, dan Kalasan bahkan Borobudur merupakan salah satu keajaiban dunia. Semua itu bisa terwujud karena adanya kerja sama dan hubungan yang baik antara raja yang memerıntah pada masa itu dengan rakyat. Hal itu disebabkan adanya rasa persatuan dan kesatuan rakyat Jawa Tengah. Kenyataan telah membuktikan bahwa tanpa bersatunya kerajaan-kerajaan dı Nusantara seperti terlihat pada masa jayanya kerajaan Majapahit, maka kerajaan-kerajaan kecil mungkin tidak akan ada artinya dalam percaturan dunia seperti sekarang.

Beitolak dari uraian di atas, maka dirasa perlu mengetahui hubungan Jawa dan Bali abad $X-X I$. Abad itu merupakan peristiwa yang menarik yartu terjadinya perkawinan antara raja Udayana darı keluarga raja Warmadewa di Bali dengan Çri Gunapriyadharmapatni keturunan raja Sindok dari Jawa Timur. Perkawinan ini ternyata menarik untuk dikaji. Uraian berikut akan mencoba mengkaji seberapa Jauh peranan $C_{i 1}$ Gunapriyadharmapatnı dalam hubungan Jawa-Bali. Sumber utama yang digunakan sebagai bahan kajian dalam penulisan ini adaiah beberapa prasasti dan peninggalan arkeologi khususnya arca-arca yang mempunyai kaitan dengan Çri Gunapriyadharmapatnı.

\section{II. Çri Gunapriyadharmapatni Peranannya Da- lam Hubungan Jawa - Bali \\ 2. Pemerintahan}

Dari 5 buah prasasti yang diterbitkan oleh Udayana selama pemerintahannya ( \pm 22 tahun) 4 buah prasasti diantaranya memberı peturjuk bahwa Udayana memerintah bersama permaısunnya Çri Gunapriyadharmapatni. Sedangkan prasastı nomor 305 Batur Pura Abang A berangka tahun 933 C, hanya menyebutkan baginda seorang dırı tanpa disertai permaisurinya Kenyataan menunjukkan bahwa Udayana memerintah bersama permaisurinya. Bahkan dalam 4 buah prasasti yang diterbitkan, nama permaısurınya justru ditulis lebih dahulu dari nama Baginda Hal ini dapat dilihat kutipan berikut

maruhani Çri Dharmodayana Warmadewa umunugraha tu anak banua di banwa bharu (Goris, 1954a. 80)

Aıtinya. Pada saat sang ratu Çri Gunapriyadharmapatnl dan sang raja f̧rı Dharmodayana Warmadewa menganugrahi penduduk di De. sa Bharu

Cara penyebutan demıkıan itu berbeda dengan kebiasaan menyebutkan pasangan raja suami-istri dalam sejarah Bali Kuna. Bıasanya sang raja disebutkan lebih dahulu daripada permaisurinya. Hal ini terlihat antara lain darı kutipan prasasti sebagai berikut

tatkalan tyurun anugrahan sang ratu Çr af (taba)nendra warmadewa mesang ratu Çr Subhadrika da (r) mmadewi... (Goris, 1954a. 14)

Dari kutipan di atas, raja Tabanendra War. madewa disebutkan lebih dahulu dari permai surinya. Sehubungan dengan penyebutan Ç. Gunapriyadharmapatni lebih dahulu dari suaminya, Goris menduga Gunapriya mempunyaı pe ngaruh yang lebih dominan dalam bidang peme rintahan daripada suaminya $\mathrm{Hal}$ ini mungkın $\mathrm{d}$ sebabkan besarnya pengaruh Jawa Tımur terhadap Bali pada masa itu. Selaın itu sepert diketahui pada prasasti Pucangan (Calcuta) Gunapriya berhak atas takhta Jawa Timur sebagai Dutr Çri isanatunggawijaya.

Di bidang struktur pemerintahannya Udayana mempunyai sistem yang teratur dengan sis. tem birokrasinya baik di tingkat pemerintahan pusat maupun di tıngkat desa. Maka pada waktu pemerıntahan raja Udayana, raja dan permaısurı merupakan pucuk pemerintahan dan pemegang kekuasaan yang tertinggi. Raja dibantu oleh sua tu Badan Penasehat Pusat yang disebut dengan Istilah: Pakıran-kiran i jro maka-baihan istilah inı baru muncul pada pemerintahan raja Udyana yartu tahun $1001 \mathrm{M}$. Badan Penasehat Pusat inı beranggotakan beberapa orang senapati, pendeta 
Siwa dan Buddha, dan kelompok Samgat $\mathrm{Hal}$ yang menarik dan perlu dicatat adalah pada pemerintahan Udayana dan Gunapriya di Bali, secara autentik dalam prasasti menyebutkan pemuka agama Siwa dan agama Budha duduk seba. gał anggota Badan Penasehat Pusat mendampingi raja dalam melaksanakan tugas sehari-hari. Kelompok pemuka agama Siwa dan Buddha mempunyai kedudukan yang cukup penting. $\mathrm{Hal}$ Inı tampak darı kehadiran mereka saat persidangan yang diadakan raja.

\section{2 Politik}

Di bidang hubungan politik bisa dicatat bahwa perkawinan Udayana dengan Gunapriyadharmapatni lebih mempererat hubungan kedua wilayah. Hal ini merupakan permulaan proses terwujudnya cita.cita persatuan dan kesatuan bangsa. Perkawinan Udayana dengan Gunapriya yang dilaksanakan secara penetration pacifique (proses meresap secara damai) menyebabkan jawa dan Bali mengadakan hubungan secara berlanjut (Goris, 1974:10). Hal Ini bisa terjadi dan dipahamı terutama jika didasarkan atas eratnya nubungan Jawa dan Ball yang telah ada sejak masa-masa sebelumnnya. Bukti hubungan seoertı itu dapat dilinat pada masa pemerintahan raja Kertanegara di Kerajaan Singasarı

Raja Kertanagara adalah seorang raja SIngasarı yang terkenal baik dalam bidang politik maupun keagamaan. Dalam bidang politik ia terkenal sebagal seorang raja yang mempunyai gagasan perluasan Cakrawaja mandała untuk mengımbangı ancaman kekuasaan Khubilai Khan darı daratan Cina. Dalam kitab Nagarakertagama diuraıkan keberhasilan raja Kertanagara menguasal hampir seiuruh nusantara antara lain disebutkan dalam Malayu tahun 1275 M, Bali tahun 1284 $M$. demikian pula daerah-daerah lainnya yaitu $\mathrm{Pa}$ hang (Malaysia): Gurun (nama pulau di Indonesia bagian tımur). Bakulapura atau Tanjungpura (baratdaya Kalimantan). Dengan kata lain hampir seluruh Nusantara sudah berhasil dipersatukan di bawah raja Kertanagara (Foesponegoro. 1984)

Seperti telah diuraikan di atas karena Cri Wijaya Mahadewi berkuasa di Bali, maka raja Udayana pergı ke Jawa Timur dan setelah perkawinannya dengan Mahendradatta mereka kembali ke Balı dan memerintah berdua menggantikan Çri Wijaya Mahadewi. Airlangga adalah putra pertama yang lahır di Bali tahun 922 C (Goris, 1948:7). Kemudian ia pergi ke Jawa Timur untuk menikah dengan putri Dharmawangsa, yang kemungkinan masih keponakan ibunya. Seperti diketahui, Airlangga masih keturunan Sindok melalu darah ibundanya. Kemudian pada tahun 941 C la dinobatkan menjadi raja Jawa Timur.
Gagasan persatuan nusantara berianjut terus dan tampak jelas pada masa pemerintahan Hayam Wuruk (1350-1389), dengan patihnya Gadjah Mada. Raja Hayam Wuruk berhasil mem. bawa kerajaan Majapahit ke puncak kebesarannya. Seperti halnyo raja Kertanagara yang mempunyai gagasan politik perluasan Calkrawala mendala yang meliputi seluruh dwipantara, Gajah Mada ingin melaksanakan politik nusantaranya yang telah dicetuskan sebagai sumpah palapa Dalam rangka menjalankan politik nusantara-nya Itu satu demi satu daerah-daerah yang belum bernaung di bawah panji Majapahit ditundukkan dan dipersotukan. Dari kakawin Nagarakragama dapat diketahui bahwa hampir seluruh wilayah Indonesia sekarang berhasil dipersatukan oleh Gajah Mada dı bawah panji Majapahıt (Poesponegoro, 1984:436)

\subsection{Sosial Budaya \\ 2.3. 1 Bahasa}

Dari data-data prasasti yang ada dapat $d$ ketahui bahwa prasasti-prasastı yang terbıt dı Balı sebelum pemerintahan raja Udayana semuanya memakai bahasa Bali Kuna Sejak pemerintahan raja Udayana dan Çrı Gunapriyadharmapatnı darı 5 buah prasasti yang dikeluarkan, 2 prasastı yaitu prasasti Bebetin A II tahun 911 C dan prasasti Serai A II tahun 915 Ç menggunakan bahasa Balı Kuna. Sedangkan 3 buah prasasti lainnya yaltu prasasti Bwahan A tahun 916 C, prasasti Sading tahun 923 C, dan prasasti Pura Abang $A$ tahun 933 C. menggunakan bahasa Jawa kuna Selanjutnya secara berangsung-angsur pemakaian bahasa Bali Kuna ditinggalkan (Ardana,dkk, 1984 28). Hal ini menunjukkan bahwa Gunapriyadharmapatni sebagai putra raja Jawa Timur menjalankan peranannya ditentukan dengan perkamnan dan pemerintah Udayana. Demikian besarnya peranan Gunapriya, sehingga dapat mepengaruhi prasasti-prasastı yang sampaı masa itu ditulis dalam bahasa Bali Kuna, selanjutnya diundangkan dalam bahasa Jawa Kuna (Goris, 1974:12)

\subsubsection{Peninggalan ankeotogi}

Dari peninggalan arkeologı akan diuraikan khususnya tentang arca perwujudan sebagai berikut

1). 2 buah arca berpasangan yang terdapat di pura Tegeh Koripan, Kintamani

Arca l: Arca berpasangan, arca perempuan berdiri di sebelah kiri arca laki. Arca berpasangan ini berdiri di atas bantal padma dan di antara keduanya dipisahkan oleh dinding pemisah. Kedua arca, tangannya memegang kuncup padma diletakkan di depan perut 
Pada bagian belakang arca terdapat angka tahun $933 \mathrm{C}$.

Arca II: Arca berpasangan dalam sikap duduk Arca laki-laki bersila, sedangkan arca perempuan bersimpuh. Kedua arca tidak dibatasi oleh dinding. Melihat style dan pakaian kebesarannya menunjukkan persamaan dengan arca l, sehingga diperkirakan mungkin keduannya dibuat oleh seniman yang sama. Arca ini berasal dari sekitar tahun 922 Ç.

Kedua Arca berpasangan tersebut diduga sebagai arca perwujudan raja Udayana dan Çrı Gunapriyadharmapatni (Stuttherheim, 1926: 38).

2). Arca Durga Mahisasuramardhini di pura Bukit Dharma, Kutri, desa Buruan, Gianyar. Diduga arca ini perwujudan Çri Gunapriyadharmapatnı yang diperkirakan wafat sebelum tahun 933 Ç, atau 929 Ç. Arca Durga ini berdiri di atas seekor lembu yang ekornya dipegang oleh tangan kanan Durga. Laksana arca Durga tersebut

- bertangan delapan, tetapi yang utuh hanya enam buah

- laksana tangan kanan masing-masing memegang cakra, anak panah dan lembing

- laksana tangan kiri masing-masing memegang cangka bersayap, busur dan perisai

Di Jawa Timur dari masa yang sama belum atau tidak ditemukan arca perwujudan. Arca permujudan semacam itu baru ada setelah Airlangga wafat (1042 M) dan di-dharma-kan di candi Belahan dalam perwujudannya sebagai Wisnu di atas garuda (Kempers, 1959:70) Arca perwujudan lainnya dari Jawa Timur Ialah arca Prajnaparamita yang indah dan didapatkan di Singasarı Arca ını diperkirakan perwujudan Ken Dedes, istri Ken Arok dan pernah disimpan di Museum Leiden oleh pemerintah Belanda. Sekarang disimpan di Museum Nasıonal. Dari bukti-bukti tersebut di atas memberikan suatu gambaran bahwa kemungkinan arca perwujudan lebih dahulu ada di Bali daripada di Jawa. Di dalam kitab Nagara. krtagama arca perwujudan disebut pratista yang proses pendiriannya berhubungan dengan upaca. ra Craddha, ialah suatu upacara selamatan bagi orang yang telah meninggal berdasarkan keikhlasan dan perasaan kasih sayang. Upacara Craddha yang diuraikan dalam kitab Nagarakitagama adalah upacara Craddha untuk Gayatri oleh cucunya Hayam Wuruk raja Majapahit

Martha A Muusses mengidentifikasikan yajnya Craddha dengan upacara memukur di Balı, yaitu upacara mengembalikan atma ke unsur asalnya yaitu paramatms. Dengan demikian, maka kemungkinan upacara memukur yang hingga sekarang dilaksanakan di Bali merupakan wari- san tradisı Yadnya Craddha dari zaman Majapahit. Walaupun tidak sama pelaksanaannya, namun arti dan fungsinya tidak berbeda

Memperhatikan hal-hal tersebut di atas besar kemungkinan terjadinya proses pengaruh mempengaruhi secara timbal balik, dalam arti Bali turut ambil bagian secara aktif di dalam proses tersebut. Sehingga dalam hal ini mungkin saja kebudayaan Bali juga mempengaruhi Jawa Timur, demikian juga sebaliknya kebudayaan Jawa Timur mempengaruhi Bali

\section{Penutup}

Çri Gunapriyadharmapatni permaisuri raja Udayana, adalah seorang tokoh wanita dalam sejarah Indonesia kuna mempunyai kedudukan dan peranan penting di bidang pemerintahan, politik dan sosial kebudayaan. Di bidang pemerintahan Gunapriya mempunyai kedudukan dan peranan yang lebih dominan daripada suaminya. Selain itu sejak pemerintahannya secara autentik disebutkan dalam prasasti, para pemuka agama Siwa dan Buddha duduk sebagai anggota Badan Penasehat Pusat (Pakiran-kiran i jro makabaihan), mendampingi raja dalam melaksanakan tugas sehari-hari.

Perkawinan Udayana dan Çri Gunaprıyadharmapatni yang dilaksanakan secara penetration pacifice (proses meresap secara damai) menyebabkan Bali dan Jawa mengadakan hubungan secara berkelanjutan dan lebih erat lagi. Keadaan yang demikıan merupakan awal mula proses perwujudan cita-cita persatan dan kesatuan bangsa yang perlu dibina dan dikembangkan secara terus menerus.

Sejak pemerintahan raja suami-istri inı, di Bali prasasti-prasasti mulai mempergunakan bahasa Bali kuna. Sedangkan di bidang kebudayaan besar kemungkinannya terjadi proses pengaruh mempengaruhi secara timbal balik antara kebudayaan Bali dan Jawa Timur.

\section{KEPUSTAKAAN}

Ardana,I Gusti Gde,1984. Laporan Penelitian di Bali.

Callenfells,van Stein,1926. Epigraphia Balica. dalam VBG LXVI derde Stuk, Batavia

Capeller,Cari, 1891. A Sanskrit-English Dictionary. Strassburg: Karl J Trubner.

Goris, R., 1948. Sejarah Bali Kuna Singaraja 
Goris, R.,1954a Prasasti Bali I, Bandung: Masa Baru

Goris R,1957. Dinastı Warmadewa Dan Dharmawangsa di Puiau Bali, dalam Bahasa dan Budaya No. 3 Tahun V, Jakarta

Goris R,1974.Beberapa Data Sejarah dan Sosiologi Dari Piagam-Piagam Bali, Jakarta, Bhratara

Nurhadi Magetsari dkk. 1979. Kamus Arkeologi Indonesia 2, Jakarta

Kempers, A.I.Bernet 1959. Ancient Indonesian Art Massachusett: Harvard University Press

Poesponegoro, Marwati Djoened, 1984. Sejarah Nasional Indonesia II. Jakarta:P.N. Balai Pustaka.

Soekmono,R., 1973.Pengantar Sejarah Kebudayaan Indonesia 2 Yogyakarta:Penerbit Ka. nisius

Stutterheim, W.F. 1926. Oudheden van Bali I. II, Singaraja: Kirtya Leifrink Van der Tuuk 